\title{
Thermal Runaway Characteristics of a Large Format Lithium-Ion Battery Module
}

\author{
Ximing Cheng ${ }^{1, * \mathbb{D}}$, Tao $\mathrm{Li}^{1}$, Xusong Ruan ${ }^{2, *}$ and Zhenpo Wang ${ }^{1, *}$ \\ 1 National Engineering Lab for Electric Vehicles, School of Mechanical Engineering, Beijing Institute of \\ Technology, Beijing 100081, China \\ 2 BNET Blueway New Energy Technology Co. Ltd., Huizhou 516006, China \\ * Correspondence: cxm2004@bit.edu.cn (X.C.); ruanxusong@desay.com (X.R.); zhenpowang@bit.edu.cn (Z.W.)
}

Received: 21 July 2019; Accepted: 8 August 2019; Published: 12 August 2019

\begin{abstract}
The overheat abuse experiment of a 12S1P 37 Ah prismatic Lithium-ion battery module in a nominal energy of $1.65 \mathrm{kWh}$ is conducted in this work. The cell behaviors and characterization in the process of thermal runaway propagation is investigated, including the gas eruption, the fire ejection, the flame combustion, the audio features, and the heat transfer, respectively. In the experiment, the central cell is heated on both sides until the pole temperature moves beyond $300{ }^{\circ} \mathrm{C}$, the thermal runaway undergoes about $43 \mathrm{~min}$ and propagates from the central to both sides in the module, and all 12 cells burn. Results show that the first three runaway cells spout gas at first, and, then, emit sound with close amplitudes, frequencies, and energies, about $200 \mathrm{~s}$ earlier than the fire ejection. Then, the characteristic of the internal short circuit is the temperature rate zone of $1.0 \mathrm{~K} / \mathrm{s}$ with time greater than $20 \mathrm{~s}$. Moreover, the proposed thermal propagation coefficient is used to assess the thermal propagation capabilities of the runaway cells on their adjacent cells, and this explains the runaway sequence. It is anticipated that the experimental results can provide the deep understanding, thermal runaway warning, and evaluation method for the module safety design.
\end{abstract}

Keywords: lithium-ion battery; thermal abuse; thermal runaway propagation

\section{Introduction}

Electric vehicles run efficiently with zero emissions, benefit sustainable development, and grow rapidly. In China, the sales of battery electric vehicles reached 652,000 in 2017, which is an increase of $59.4 \%$ compared to 2016. The onboard lithium-ion battery (LIB) capacity exceeded $37 \mathrm{GWh}$, of which average capacities of electric cars and buses, respectively, were $30 \mathrm{kWh}$ and $60 \mathrm{kWh}$. Among them, the proportions of the prismatic, the cylinder, and the pouch cells were about $59 \%, 28 \%$, and $13 \%$, respectively. Today, millions of battery electric vehicles run on the road. Their safety has always been considered because LIBs can have thermal runaway due to abuse [1].

The overheated LIBs can catch fire or even explode and cause a lot of property damage or personal jury. Smart phones are usually powered by one LIB. If the LIB is abused mechanically, its phone can be on fire. In the second half of 2016, millions of the Galaxy Note 7 were recalled from the spontaneous combustion of LIBs with internal short circuit (ISC) by either squeezing the batteries or puncturing the separators at the solder joints. Compared to smartphones, one electric vehicle is powered by hundreds of thousands of LIBs so that its thermal runaway should be more prone to occur. On 4 March 2017, one Tesla Model $\mathrm{S}$ burned out due to its battery part being on fire while charging at one super charge station in Shanghai, China. It was reported that there were at least 14 pure electric vehicles to ignite spontaneously while they were in operation, charge, and park from June to August of 2018 in China. These battery runaway hazards can be attributed to the severe exothermic reactions inside the LIBs caused by mechanical, electrical, and thermal abuses [2]. 
The thermal runaway mechanism of one LIB was systematically summarized in several reviews [3-8]. For an example, the energy release diagram was proposed to quantify the chain-reaction kinetics for cell materials in the uncontrolled process [8]. However, the thermal propagation behavior and mechanism of battery modules or packs needs to be further investigated due to the complex thermal interactions among cells. During thermal runaway, a large amount of heat is released in a short time in the battery module, the extension of which can be influenced by abuse types, module structures, shell shapes, electrical connections, energy levels, and heat dissipation modes.

The series-parallel structure of cells affects the thermal runaway propagation behaviors of battery modules. When thermal runaway is triggered by the external short circuit, the propagation of cells in parallel is more intense than that of the batteries in series. Under the condition of needling the central cell of 18,650 modules, Lamb et al. [9] found that each cell in parallel underwent thermal runaway in an 1S10P module and only the penetrated cell initiated runaway in a 10S1P module. Even if cells are in parallel, their pole connection modes also have effects on the thermal propagation in battery modules. Lopez et al. [10] validated that the electric connection of the M-type could reduce thermal hazards compared with that of the S-type when overheating the central cell in a 1S9P 18,650 module.

If the heat transfer area between cells is large, the pole connection types have little influence on the thermal propagation in a module. For instance, the cells were arranged tightly and contacted with a large area in both 1S5P and 5S1P pouch modules. The central cell was punctured to cause similar results in these two modules. All cells underwent thermal runaway and eventually charred [9]. Jeevarajan et al. [11] investigated an external short circuit test of an $8 \times 818,650$ module and found that the matrix configuration prevented the lateral propagation of fire even though some cells caught fire and exploded.

The energy level of the cell is one of several important factors of the thermal propagation in battery modules and is often characterized by a state of charge (SOC). Additionally, it is characterized by higher SOC, more energy, and easier to trigger thermal runaway. In the $2 \times 2$ matrix configuration of an 18,650 module, Ouyang et al. [12] set up a round rod heater with the same size as the cell. It was found that the higher the SOC is, the earlier the thermal runaway of the battery module is, the faster the heat spread is, and the higher the surface temperature of cells is. Zhong et al. [13] conducted the thermal abuse experiment of battery modules with the $3 \times 3$ matrix structure of $100 \%, 50 \%$, and $0 \%$ SOC. By using the same $100 \mathrm{~W}$ heating power, the higher the SOC became and the more intense the thermal runaway of the module became. Clearly, when a module has more cells, it can lead to more intense thermal runaway. Additionally, a model simulation showed that the whole module could be thermal runaway when the exothermic reaction heat of one runaway cell increased slightly [14].

Spacing increase and heat insulation materials can lessen heat transfer between cells, which inhibits the thermal runaway propagation in a module. For example, the cell gap increased from $0 \mathrm{~mm}$ to $2 \mathrm{~mm}$ to reduce the risk of thermal runaway propagation in a module [10]. By comparing the thermal propagation process of $3 \times 318,650$ cylindrical battery modules with two kinds of spacing, it was found that the surface temperature of cells near the runaway cell in the batteries with $0 \mathrm{~mm}$ gap rose more rapidly than that with $4 \mathrm{~mm}$ gap [13]. Furthermore, one kind of heat-resistant fiber material with a multi-layer high reflective metal foil was also used as the thermal radiation barrier to block the thermal transmission of high temperature explosives and flames to adjacent cells [10]. In addition, other researchers investigated the inhibitory effects of integrated aluminum radiators, micro-porous coolers, and phase change materials on the thermal runaway propagation in battery packs [15-17].

By the available literature, the thermal runaway propagation of large prismatic cells was studied less than that of cylindrical and pouch cells in modules. Feng et al. [18] investigated the thermal runaway propagation mechanism of prismatic battery modules by penetrating the first large format cell on the side, including temperature responses and heat transfer passages of six batteries in series. By overheating the first side cell, Li et al. [19] carried out the thermal abuse tests of the module composed of five prismatic cells with different SOC levels and validated that the module with $100 \%$ SOC had more intense combustion behavior and shorter average propagation time than that with $50 \%$ 
SOC. In battery modules, the heat released from the side cell in thermal runaway should be transferred to other cells than that from the central cell.

In onboard battery packs, prismatic cells are arranged face-to-face and their poles interconnect through aluminum or copper bars. The group mode of prismatic cells is simple, sturdy, and durable, which makes them load greatly on electric vehicles. However, it is difficult for the central cells to dissipate heat because of the long distance of the heat transfer inside a battery module. Thus, compared to the side cells, the central cells can be overheated into thermal runaway to cause the most intense thermal runaway propagation in a battery module. Due to high cost, risk, and difficulty, there is little literature to investigate the central thermal abuse of a large format LIB module. In this work, the central cell overheated on both sides in a 12S1P LIB module sample, which was used to explore the phenomena, triggered sequence, and characteristics of thermal abuse cells for evaluating the thermal isolation capability and early warning of prismatic battery packs for electric vehicles.

\section{Experimental Setup}

In this experiment, the battery cell is a commercial 37 Ah energy-power prismatic LIB with the lithium nickel cobalt manganese oxide (NCM) cathode, the graphite anode, and the polypropylene (PP) separator. It is $26.5 \mathrm{~mm}$ thick, $148 \mathrm{~mm}$ long, $92.4 \mathrm{~mm}$ high, and about $805 \mathrm{~g}$. The aluminum shell of the battery is $0.7 \mathrm{~mm}$ thick, coated with an electricity insulation layer, and electrically connected with its positive pole. There is a vent covered with an aluminum foil pressure relief valve in the middle of the shell top. When the internal gas pressure is too high, the aluminum foil can be broken to release the pressure inside the battery. Before grouped, new cells discharged down to $2.8 \mathrm{~V}$ through $1 \mathrm{C}$ current for a safe package.

Figure 1a illustrates the block diagram of the thermal abuse test of the LIB module. It consists of electric connection bars, thermocouples, aerogel interlayers, mica film heaters, temperature, power harnesses, a $220 \mathrm{~V}$ AC power supply, a data acquisition computer, a digital camera, and LIB samples, as shown in Figure 1b. Figure 1c shows the module sample composed of 12 cells in series. The positive and negative terminals between adjacent cells are connected by a laser welded aluminum bar. A layer of 0.3-mm thick mica is laid between the terminal interconnection bars, with which vents are covered. Additionally, the 12S1P module is packed in a steel alloy box without a top cover.

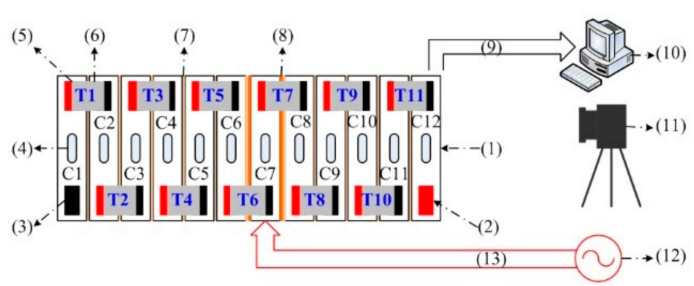

(a)

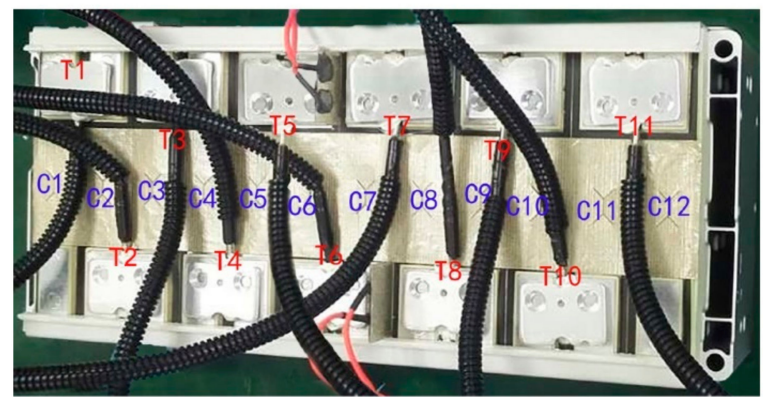

(c)

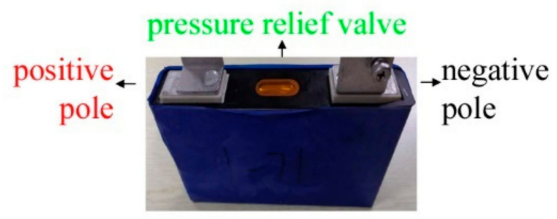

(b)

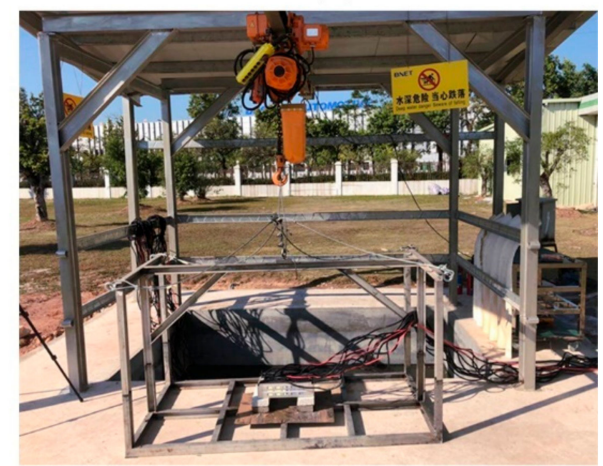

(d)

Figure 1. Experimental setup: (a) schematic, (1) cell, (2) positive pole, (3) negative pole, (4) pressure relief valve, (5) aluminum bar, (6) thermocouple, (7) heat insulation interlayer, (8) heater, (9) signal harness, (10) data logger, (11) video camera, (12) AC power supply, (13) power harness, (b) cell sample, (c) battery module, and (d) test field. 
In order to block the thermal runaway spread, the 0.8 -mm thick aerogel were placed between adjacent cells to reduce the heat transfer between cells. On both sides of the central cell C7, a customized mica heater of $0.3-\mathrm{mm}$ thickness and $400 \mathrm{~W}$ was installed. Four red wires powered these two heaters. Under every terminal connector, one thermocouple was installed. Eleven thermocouple wires with black bellows connected to a data acquisition computer.

The experimental site for battery packs is a ventilated outdoor building, whose flat roof is supported by four steel columns. Under this building, there is a $2 \mathrm{~m} \times 2 \mathrm{~m} \times 1 \mathrm{~m}$ water tank with a depth of about $300 \mathrm{~mm}$, as shown in Figure 1d. The battery pack sample was supported by cement bricks placed on a plank on a steel frame. Before the test, the steel frame was hoisted on the water tank and was $100 \mathrm{~mm}$ above the water surface. Before the test, the 12S1P battery pack was charged fully by using the $1 \mathrm{C}$ current. On a bright day, the initial ambient temperature was about $19{ }^{\circ} \mathrm{C}$. Once the pole temperatures measured by either $\mathrm{T} 6$ or $\mathrm{T} 7$ reached $300{ }^{\circ} \mathrm{C}$, the external heaters were powered off. For the tested battery samples, the NCM cathode materials can have the highest decomposition temperature close to $300{ }^{\circ} \mathrm{C}$ [8]. Therefore, the central cell was heated on both sides up to the pole temperature of $300^{\circ} \mathrm{C}$ to activate a complete thermal runaway process.

In the tested battery module, each sample cell has the operation voltage range of $2.8 \sim 4.2 \mathrm{~V}$, the operation temperature range of $-20 \sim 60^{\circ} \mathrm{C}$ for discharging, and $0 \sim 60^{\circ} \mathrm{C}$ charging, and the current rates up to $6{ }^{\circ} \mathrm{C}$ for discharging and charging. During the test, the pole temperatures are only detected by 11 thermocouples in an accuracy of $\pm 1{ }^{\circ} \mathrm{C}$ for the battery temperature responses.

\section{Results and Discussion}

After C7 was heated for about $9 \mathrm{~min}$, either gas eruption or flame burning appeared one by one cell from the central to both sides of the 12S1P battery module. The process of the thermal abuse of batteries lasted nearly one hour. During thermal runaway, the battery module occurred four typical phenomena including the smoking, gas eruption, fire ejection, and flame combustion. All 12 battery cells burned. Among them, C7 was the first cell to start thermal runaway at $552 \mathrm{~s}$ after the test began. Then, the whole module underwent thermal runaway from cell to cell. The $\mathrm{C} 1$ flame was the last to die.

\subsection{Gas Eruption}

After the battery module was thermally abused, the short gas eruption of $C 7$ became the first phenomenon for about $200 \mathrm{~s}$ before ignition. In addition to C7, there are six cells including C6, C8, C5, C10, C12, and C2 to first vent gas, as shown in Figure 2.

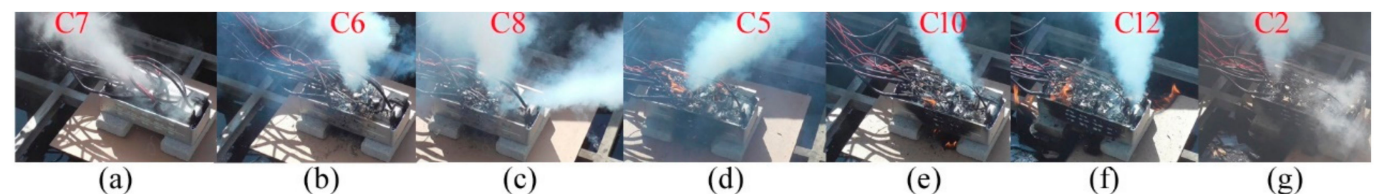

Figure 2. Gas eruption at first.

The colors, directions, and shapes of these jet gases are different. The jet gas color is either pink, white, or cyan white. The four cells of C7, C6, C8, and C2 spouted out the pink white gas in Figure 2a-c,g. Others did the cyan white gas in Figure 2d-f. During thermal runaway, the cells could change the vent gas colors. Venting from C6 between $1107 \mathrm{~s}$ and $1132 \mathrm{~s}$, the gas changed colors from white to cyan and from cyan to white, as illustrated in Figure 3. The change of gas colors should result from its composition and temperature. Table 1 lists the pole temperatures of $\mathrm{C} 6$ while venting. Meanwhile, the pole temperatures of T5 was much lower than that of T6. However, the pole temperature of $\mathrm{T} 5$ had a high rise of $136.5 \mathrm{~K}$, which is more than four times of that of $\mathrm{T} 6$. As for the gas eruption direction, it can be influenced by the wind direction and the mica cover on the relief valve. 


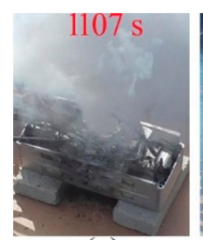

(a)

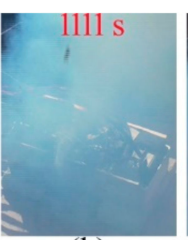

(b)

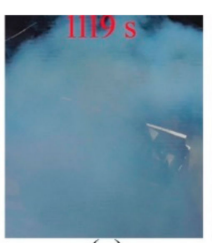

(c)

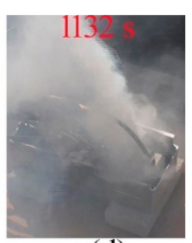

(d)

Figure 3. Color changes of jet gas of C6 between $1107 \mathrm{~s}$ and $1132 \mathrm{~s}$.

Table 1. Pole temperatures of C6 in Figure 3.

\begin{tabular}{ccccc}
\hline Subplots in Figure 3 & a & b & c & d \\
\hline Gas colors & white & cyan & cyan & white \\
\hline T5 $\left({ }^{\circ} \mathrm{C}\right)$ & 176.6 & 196.4 & 249.4 & 313.1 \\
\hline T6 $\left({ }^{\circ} \mathrm{C}\right)$ & 383.1 & 383.5 & 394.4 & 416.6 \\
\hline
\end{tabular}

At the time of the gas eruption of above seven battery cells, the pole temperatures varied between $94.7^{\circ} \mathrm{C}$ and $444.6^{\circ} \mathrm{C}$. The jet gas mainly comes from the following aspects. First, the gas originates from the solvent vaporization due to the boiling points of $90 \sim 130{ }^{\circ} \mathrm{C}$ for DMC, EMC, and DEC. The LiPF6 salt decomposes from room temperature and aggravates solvents to generate gas beyond $160{ }^{\circ} \mathrm{C}[20,21]$. Second, the SEI layer decomposes to around $100^{\circ} \mathrm{C}$ [22-24]. The SEI layer renews with incomplete passivation from 120 to $170{ }^{\circ} \mathrm{C}$, and the litigated graphite and electrolyte reacts under $200{ }^{\circ} \mathrm{C}$. Additionally, the graphite-lithium-organic molecule intercalation compounds decompose above $230{ }^{\circ} \mathrm{C}$ with gas evolution [25]. Third, the $\mathrm{NCM}$ cathode material of $\mathrm{Li}_{0.33} \mathrm{Ni}_{1 / 3} \mathrm{Co}_{1 / 3} \mathrm{Mn}_{1 / 3} \mathrm{O}_{2}$ in electrolyte can decompose to generate oxygen above $236{ }^{\circ} \mathrm{C}$ [26]. The venting gas of $51 \mathrm{NCM}$ cells in thermal runaway is mainly composed of $\mathrm{CO}_{2}, \mathrm{CO}, \mathrm{H}_{2}, \mathrm{CH}_{4}$, and $\mathrm{C}_{2} \mathrm{H}_{4}$ with an average concentration of $36 \%, 28 \%, 22 \%, 5 \%$, and $5 \%$, respectively, where the volume is influenced by both cell capacity and energy density [27]. In other studies, the toxic ingredients of $\mathrm{HF}$ and $\mathrm{POF}_{3}$ has been detected in the venting gas [28]. Once the combustible conditions of the venting gas are all attained, it will ignite. Therefore, the gas eruption of a cell would indicate fire in near real-time. The experimental results show that these cells spent different time periods from gas eruption to ignition. The maximum, average, and minimum intervals between these two phenomena are $218 \mathrm{~s}, 125 \mathrm{~s}$, and $1 \mathrm{~s}$, respectively.

\subsection{Flame Combustion}

Ahead of gas eruption, the five cells of C9, C4, C11, C3, and C1 burned first, as shown in Figure $4 \mathrm{a}-\mathrm{e}$. The onset pole temperatures had the minimum value of $127.7^{\circ} \mathrm{C}$ and the maximum value of $500{ }^{\circ} \mathrm{C}$. Among them, the jet gases of $\mathrm{C} 9$ and $\mathrm{C} 4$ were ignited to form a large fire by the flames of $\mathrm{C} 8$ and C10, respectively. However, C11, C3, and C1 self-ignited with a small fire. C11 burned at its vent, which is the same as $\mathrm{C} 9$ and $\mathrm{C} 4$. Both $\mathrm{C} 3$ and $\mathrm{C} 1$ were on fire on the shell sides. It was possible for the welding seam between the top cover and shell body to breach for the internal fire venting by using a high temperature and pressure.

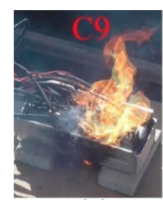

(a)

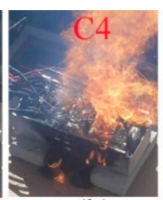

(b)

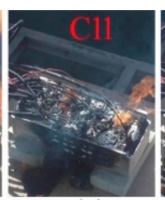

(c)

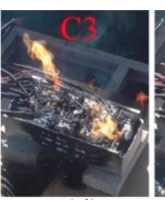

(d)

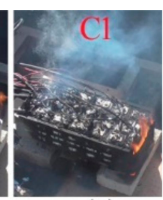

(e)

Figure 4. Fire ejection at first.

It is probable for the high temperature venting gas to ignite due to the combustible ingredients of $\mathrm{CO}, \mathrm{H}_{2}$, and hydrocarbons [27,28]. Inside a battery, the ISC causes the internal temperature to move 
beyond $1000{ }^{\circ} \mathrm{C}$ [29]. A tiny amount of debris of the aluminum collector can be mixed with the gas stream, eject, and spark in air. When the concentration of one combustible gas stays between the lean flammability limit (LFL) and the rich flammability limit (RFL), it will ignite by sparks [30]. Naturally, the venting gas will catch fire by flames, and burns spontaneously when its temperature exceeds the ignition points.

It was observed that once one cell entered thermal runaway, it could burn either continuously or interstitially. After its flame was blown out, the jet gas could catch fire again. The maximum, average, and minimum values of combustion time are 517, 291, and $100 \mathrm{~s}$. In addition, there were four cells including C8, C4, C10, and C3 to erupt fire and gas alternately, in which the lasting time could exceed $10 \mathrm{~s}$. Figure $5 \mathrm{a}-\mathrm{j}$ exemplify this behavior of $\mathrm{C} 10$ from 1655 to $1664 \mathrm{~s}$. In this period of $10 \mathrm{~s}$, the jet flame and gas occurred three times alternately. The lasting time of each eruption was between $1 \mathrm{~s}$ and $3 \mathrm{~s}$. Both the pole temperatures of T9 and T10 rose from $444.2{ }^{\circ} \mathrm{C}$ to $465.4{ }^{\circ} \mathrm{C}$ and from $158.3{ }^{\circ} \mathrm{C}$ to $169.5^{\circ} \mathrm{C}$, respectively.

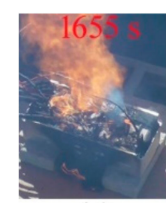

(a)

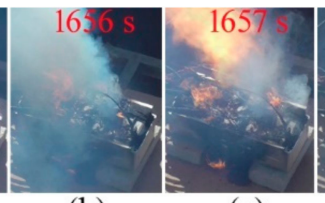

(b)

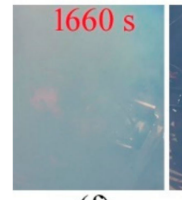

(f)

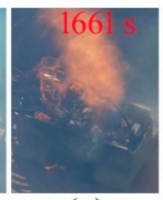

(g) (c)

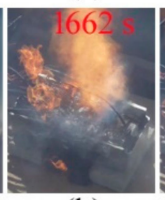

(h)

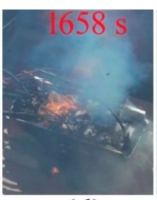

(d)

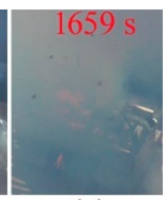

(e)

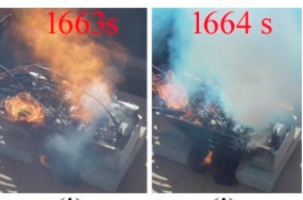

(i)

(j)

Figure 5. Alternate ejection of gas and fire.

Before the alternate eruption of both fire and gas, C10 sustained combustion. At 1637 s, the flame became large again and the pole temperatures of T9 and T10 were 419 and $148.9^{\circ} \mathrm{C}$, respectively. Although the battery separator of a monolayer PP melts and shuts down around $165^{\circ} \mathrm{C}$ [31], it starts to shrink above $60^{\circ} \mathrm{C}$, and the shrinkage increases nonlinearly and rapidly with a rising temperature. The shrinkage of a monolayer PP in the machine direction reaches $6.6 \%, 38.7 \%$, and $73.6 \%$ for $130{ }^{\circ} \mathrm{C}$, $160^{\circ} \mathrm{C}$, and $180^{\circ} \mathrm{C}$, respectively [32]. Consequently, the internal high temperatures made the PP layer contract to form the ISC between the positive and the negative electrodes. A large amount of joule heat was released to elevate internal temperature [33], and further provoked chain exothermic reactions among battery materials [8]. In the highly thermal cave, the electrolyte vaporized, decomposed, and reacted with electrodes to form gas. Plenty of gases with combustible components were produced inside the cell. After $18 \mathrm{~s}$, the fire spewed out from the safety vent and underwent the alternate fire and gas eruption. Then, the flame smoothly combusted until it was extinguished.

This is an explanation for the alternate fire and gas eruption. The exothermic reactions continue to occur under the high temperature inside the battery cell. When the gas production rate is much higher than the exhaust rate, the gas pressure inside the cell increases rapidly beyond the air pressure outside. As a result, the gas bursts out at the safety valve. If the jet gas contains enough combustible ingredients with an ignition point temperature, it will catch fire at the valve in air. When its concentration is between the LFL and RFL, the combustible gas deflagrates into fire ejection. The short fire ejection reduces the internal gas pressure when the consumption rate of the flammable gas is greater than its production rate. On one hand, with the combustible gas concentration on the decrease in the jet gas, the jet flame can die so that the gas ejects without fire. On the other hand, the high-speed jet gases can form turbulence around them and lack oxygen to extinguish flames [30]. Furthermore, it is also probable for little flames to be blown out. 
After the flame is extinguished, the combustible gas continues increasing until ignition or deflagration again. When both the consumption and production rates of flammable gas balances, and the pressure inside and outside balances, the gas can vent and burn smoothly until the end of exothermic reactions inside the battery cell. Meanwhile, the balanced pressure brings air into the battery cavity. It is possible for the flammable gas to burn with the adequate oxygen inside the cell. It can be concluded that whether the venting gas burns in air depends on its content of combustible ingredients, temperature, velocity, and density.

In addition, it was easy for the outer insulators of signal harnesses to ignite when the big fire erupted on the battery pack.

\subsection{Temperature Responses}

A pole connects the collector of a LIB cell, on which a temperature sensor can be integrated more easily and reliably than in other positions. In engineering applications, thermocouples are usually installed on battery poles to measure the temperature. Figure 6 illustrates the pole temperature response, which is divided into four phases by four straight lines A, B, C, and D. The stage I, II, III, and $I V$, respectively, denote the initial heating of the interval $A B$, the thermal runaway germination of the interval $\mathrm{BC}$, the intense thermal runaway propagation of the interval $\mathrm{CD}$, and the natural cooling of the battery debris after line D. The corresponding pole temperatures are listed in Table 2.

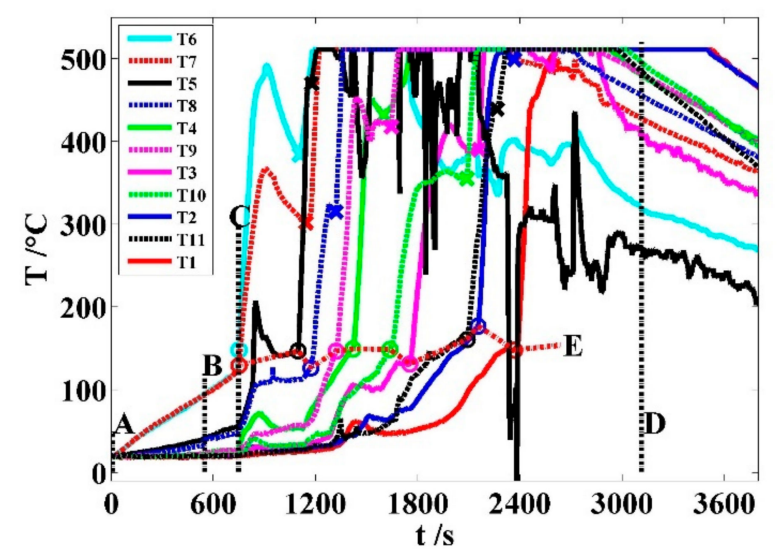

Figure 6. Pole temperature responses.

Table 2. Temperature data in Figure 6.

\begin{tabular}{ccccc}
\hline Lines & A & B & C & D \\
\hline Time $(\mathrm{s})$ & 0 & 552 & 751 & 3114 \\
\hline Phenomena & start & gas eruption & fire & extinguishment \\
\hline $\mathrm{T} 1\left({ }^{\circ} \mathrm{C}\right)$ & 18.0 & 19.9 & 20.1 & 510 \\
\hline $\mathrm{T} 2\left({ }^{\circ} \mathrm{C}\right)$ & 19.2 & 20.5 & 22.2 & 510 \\
\hline $\mathrm{T} 3\left({ }^{\circ} \mathrm{C}\right)$ & 19.9 & 21.3 & 22.1 & 406.5 \\
\hline $\mathrm{T} 4\left({ }^{\circ} \mathrm{C}\right)$ & 18.6 & 23.1 & 29.7 & 479.9 \\
\hline $\mathrm{T} 5\left({ }^{\circ} \mathrm{C}\right)$ & 19.9 & 41.2 & 57.2 & 268.7 \\
\hline $\mathrm{T} 6\left({ }^{\circ} \mathrm{C}\right)$ & 19.0 & 95 & 148.0 & 318.8 \\
\hline $\mathrm{T} 7\left({ }^{\circ} \mathrm{C}\right)$ & 19.3 & 94.7 & 129.6 & 427.2 \\
\hline $\mathrm{T} 8\left({ }^{\circ} \mathrm{C}\right)$ & 18.9 & 39.3 & 52.3 & 455.5 \\
\hline $\mathrm{T} 9\left({ }^{\circ} \mathrm{C}\right)$ & 19.2 & 22.8 & 27.4 & 481.6 \\
\hline $\mathrm{T} 10\left({ }^{\circ} \mathrm{C}\right)$ & 19.6 & 21.1 & 23.2 & 495.3 \\
\hline $\mathrm{T} 11\left({ }^{\circ} \mathrm{C}\right)$ & 19.5 & 20.2 & 20.7 & 484.6 \\
\hline
\end{tabular}


Stage I: A B. At time A, the pole temperatures are $19 \pm 1^{\circ} \mathrm{C}$. From A to B, they rose almost linearly and decrease from the central to both sides of the battery module. Among them, both $\mathrm{C} 7$ poles have the maximum average temperature rate of $0.137 \mathrm{~K} / \mathrm{s}$. At time B, C7 abruptly vented a white smoke column with the highest temperature of $95^{\circ} \mathrm{C}$, where the thermal condition can make its SEI decompose [24]. Other pole temperatures are less than the upper limit of $60^{\circ} \mathrm{C}$ of the LIB operation temperature.

Stage II: B C. At time C, C7 spouts flame at its vent and its pole temperatures reaches 167.8 and $141.1^{\circ} \mathrm{C}$ respectively, both temperatures of which cause ISC from the separator collapsing [32]. Other pole temperatures are still less than $60^{\circ} \mathrm{C}$. During the interval of $199 \mathrm{~s}$, every pole temperature almost linearly increases. Except $\mathrm{T} 6$ and T7, the temperatures of $\mathrm{T} 5$ and $\mathrm{T} 8$ rise more rapidly than that of others. The temperature rates of T6 and T7 are about twice and 1.3 times that of the phase I, respectively. Under the same thermal condition of both C7 sides, it may show that the exothermic reaction of its anode is more intense than that of its cathode.

Stage III: C $\sim$ D. At time D, the battery module kept fireless and smokeless after all cells underwent thermal runaway. The interval is $2363 \mathrm{~s}$ between $C$ and D. During this period, all 12 cells initiated thermal runaway, vented, burned, and extinguished, whose pole temperatures wildly fluctuated due to the heat generation of intermittent exothermic reactions from cell to cell. Because the pole thermocouples measure temperature with the upper limit of $510{ }^{\circ} \mathrm{C}$, all pole temperature curves have flat tops. Hereafter, these curves tend to decline.

Except for $\mathrm{C} 2$ and $\mathrm{C} 12$, other cells have two pole thermocouples. Because C7 is the first thermal runaway cell, its runaway temperatures are together measured by T6 and T7. However, the thermocouple saturation at high temperature makes the runaway temperatures of other cells only detected by one pole thermocouple. Hereinafter, the thermocouples T1 T5 and T8 T11 are matched one by one with $\mathrm{C} 2 \sim \mathrm{C} 6$ and $\mathrm{C} 8 \sim \mathrm{C} 11$, respectively.

The violent phenomena such as dense smoke eruption, fire spewing, and big fire could occur during one cell that went through ISC in the module. According to the cell positions, pole temperature data, and observed phenomena, the ISC trigger points of battery cells are plotted in circles in Figure 6. Table 3 lists the ISC data. The onset temperature range is $121^{\circ} \mathrm{C}$ to $177^{\circ} \mathrm{C}$, in which the changes have been validated by other researchers $[18,19]$. In each ISC interval, the pole temperature has a maximum value between $324^{\circ} \mathrm{C}$ and $508^{\circ} \mathrm{C}$. The variable onset temperatures stem from differential thermal conditions of each runaway cell.

Table 3. ISC data in Figure 6.

\begin{tabular}{ccccccc}
\hline \multirow{2}{*}{ Cells } & $\begin{array}{c}\text { Thermo- } \\
\text { Couples }\end{array}$ & $\begin{array}{c}\text { Onset Temperature } \\
\left({ }^{\circ} \mathbf{C}\right)\end{array}$ & $\begin{array}{c}\text { Onset Time } \\
\mathbf{( s )}\end{array}$ & $\begin{array}{c}\text { Duration } \\
\mathbf{( s )}\end{array}$ & $\begin{array}{c}\text { Average Temperature } \\
\text { Rate (K/s) }\end{array}$ & $\begin{array}{c}\text { Maximum } \\
\text { Temperature }\left({ }^{\circ} \mathbf{C}\right)\end{array}$ \\
\hline C2 & T1 & 148 & 2369 & 94 & 3.11 & $/$ \\
\hline C3 & T2 & 176.8 & 2154 & 123 & 2.68 & 507.8 \\
\hline C4 & T3 & 131.2 & 1753 & 236 & 1.23 & 420.4 \\
\hline C5 & T4 & 149.2 & 1420 & 107 & 2.8 & 452.25 \\
\hline C6 & T5 & 146.8 & 1099 & 61 & 5.36 & 474.3 \\
\hline C7 & T6 & 137.7 & 748 & 130 & 2.58 & 492 \\
\hline C8 & T7 & 121.7 & 743 & 163 & 1.51 & 367 \\
\hline C9 & T8 & 126.3 & 1172 & 108 & 1.83 & 324 \\
\hline C10 & T9 & 146.7 & 1321 & 119 & 2.58 & 453 \\
\hline C11 & T10 & 148.9 & 1637 & 163 & 1.2 & 364.1 \\
\hline
\end{tabular}

In Figure 6, the order of circles from left to right on the curve $\mathrm{E}$ can indicate the ISC sequence of battery cells in $\mathrm{C} 7 \rightarrow \mathrm{C} 6 \rightarrow \mathrm{C} 8 \rightarrow \mathrm{C} 9 \rightarrow \mathrm{C} 5 \rightarrow \mathrm{C} 10 \rightarrow \mathrm{C} 4 \rightarrow \mathrm{C} 11 \rightarrow \mathrm{C} 3 \rightarrow \mathrm{C} 2$. This coincides with the sequence of the thermal runaway initiation from cell to cell 
$\mathrm{C} 7 \rightarrow \mathrm{C} 6 \rightarrow \mathrm{C} 8 \rightarrow \mathrm{C} 9 \rightarrow \mathrm{C} 5 \rightarrow \mathrm{C} 10 \rightarrow \mathrm{C} 4 \rightarrow \mathrm{C} 11 \rightarrow \mathrm{C} 3 \rightarrow \mathrm{C} 12 \rightarrow \mathrm{C} 2 \rightarrow \mathrm{C} 1$ by the observed phenomena. When $\mathrm{C} 1$ and $\mathrm{C} 12$ triggered ISC, their pole thermocouples $\mathrm{T} 1$ and $\mathrm{T} 11$ had been over $500{ }^{\circ} \mathrm{C}$ and almost output in saturation. Hence, it is difficult for the thermal runaway processes of $\mathrm{C} 1$ and $\mathrm{C} 12$ to be detected through their own pole temperatures of T1 and T11. Each cross point in Figure 6 shows a valley bottom of a pole temperature. On one temperature curve, the maximum temperature position is sited between the cross and trigger points and indicates the ISC end of the corresponding cell.

In this stage, all 12 battery cells generated fierce exothermic reactions resulting in flame burning, including a big mushroom fire of which ignited the black corrugated pipes of the temperature signal wires over the module shown in Figure 7a.

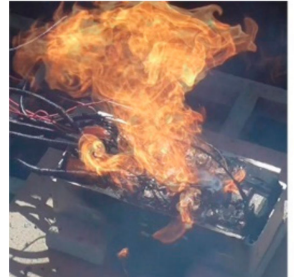

(a)

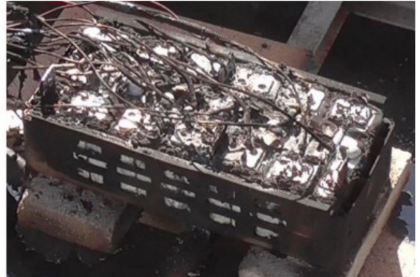

(b)

Figure 7. Harness burning and module debris: (a) harness burning and (b) module debris.

Stage IV: D . After the module terminated thermal runaway, all cells cooled naturally in the field and their pole temperatures went down. Figure $7 \mathrm{~b}$ shows the module debris. Over this pack, the insulation layers of all harnesses almost burned out and blackened wires are bare. Compared to the white aluminum terminal bars and battery shells, the box was blackened in fire. After burning, 12 cells do not collapse and are still visible in shapes.

\subsection{Temperature Rates}

At time of the circles of the curve E in Figure 6, the corresponding ISC of battery cells occurred to generate fierce exothermic reactions, which results in their own pole temperatures rising abruptly and thermal propagation to elevate adjacent pole temperatures for probable runaway. Before triggering our own ISC, one cell was impacted by a lot of heat released from other ISC batteries. In the experiment, the 12 cells in the battery pack initiated thermal runaway one by one. Thus, the pole temperature curves rose in fluctuation between $\mathrm{C}$ and each circle of the curve $\mathrm{E}$ in Figure 6. Figure 8 shows the total average values of $\mathrm{pT}_{\mathrm{AB}}, \mathrm{pT}_{\mathrm{BC}}$, and $\mathrm{pT}_{\mathrm{CX}}$ about $0.0321,0.0652$, and $0.1358 \mathrm{~K} / \mathrm{s}$, respectively. They increase progressively by approximately two times. Under the same external heat, the released heat in the module increased in turn in the stages I, II, and III.

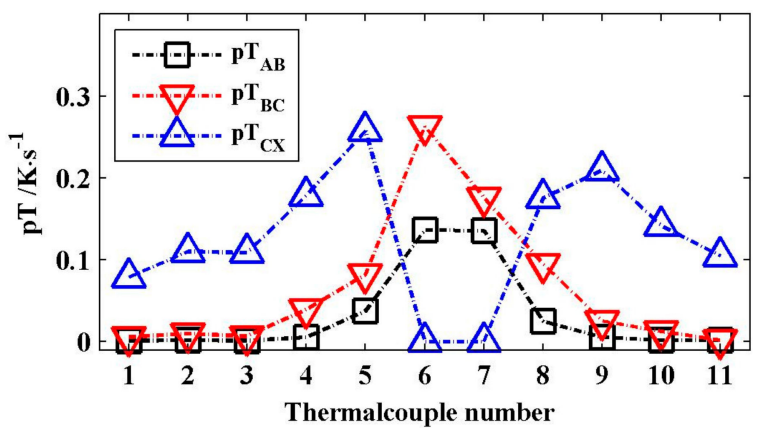

Figure 8. Average temperature rates of three stages in Figure 6: $\mathrm{pT}_{\mathrm{AB}}$ and $\mathrm{p} \mathrm{T}_{\mathrm{BC}}$, respectively, correspond to the two intervals of $\mathrm{AB}$ and $\mathrm{BC} \cdot \mathrm{pT}_{\mathrm{CX}}$ corresponds to the intervals between $\mathrm{C}$ and each circle.

In the stage III, the 12 cells occurred ISC, which could be indicated by their pole temperature rates. As for every ISC interval, its temperature rate is greater than 0 . The temperature rate interval 
(TRI) between the two vertical dot lines in each subplot of Figure 9 is matched one by one with the temperature region after each circle on the curve E of Figure 6. The shapes, amplitudes, and tendencies of these temperature rate curves are different. These 10 ISC intervals have different onset temperatures, average rates, and durations in Table 3. The average value of the onset temperatures is about $145^{\circ} \mathrm{C}$. The average rate of every interval stays between 1.2 and $5.36 \mathrm{~K} / \mathrm{s}$. The total average is $2.43 \mathrm{~K} / \mathrm{s}$, which is about 17.5 times of that of $\mathrm{pT}_{\mathrm{CX}}$. Generally, the longer the ISC duration, the smaller its average rate. The maximum, average, and minimum durations of the ISC intervals are 236, 133, and $61 \mathrm{~s}$, respectively.
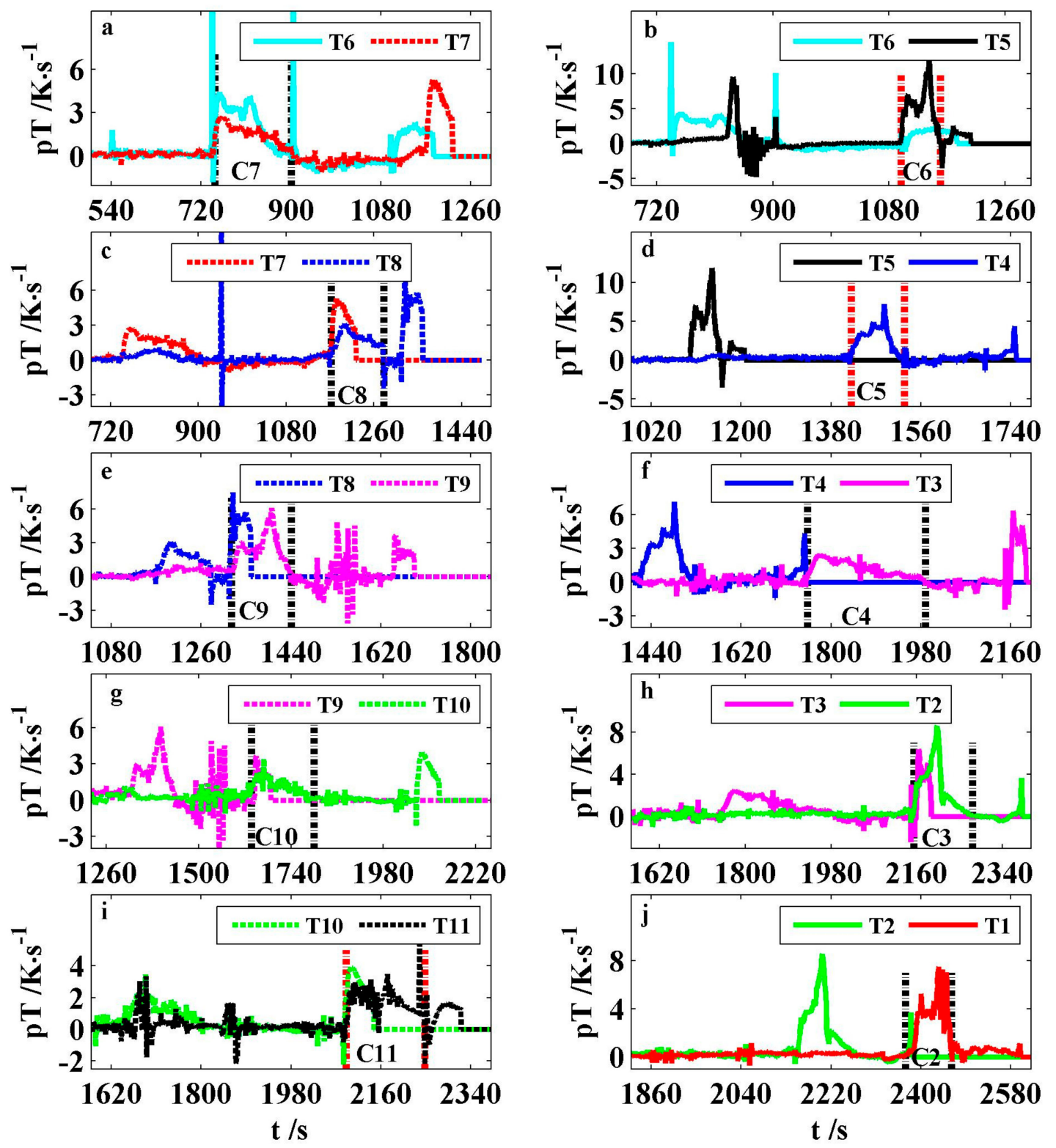

Figure 9. Pole temperature rates during thermal runaway: each ISC interval between both vertical lines in the subplots.

When the temperature rate in an ISC interval is greater than a positive real number of $\alpha$, it is expressed by the TRI of $\alpha$. Table 4 lists the characteristic data of the TRIs of 0.5 and $1.0 \mathrm{~K} / \mathrm{s}$, respectively. Their total average rates are 2.56 and $2.8 \mathrm{~K} / \mathrm{s}$, respectively. Compared to the duration of the TRI of $0 \mathrm{~K} / \mathrm{s}$, that of 0.5 and $1.0 \mathrm{~K} / \mathrm{s}$ drops by $7 \%$ and $20 \%$ on average, respectively. For the three TRIs of $0,0.5$, and $1.0 \mathrm{~K} / \mathrm{s}$, their start time is $7.6,4.5$, and $2.3 \mathrm{~s}$ on average, which is earlier than the fire ejection time, respectively. In other words, the higher the temperature rate of an ISC interval, the closer the fire. 
Table 4. Characteristic data of ISC intervals with high temperature rates.

\begin{tabular}{|c|c|c|c|c|c|c|c|}
\hline \multicolumn{2}{|c|}{ Temperature Rates } & \multicolumn{3}{|c|}{$0.5 \mathrm{~K} / \mathrm{s}$} & \multicolumn{3}{|c|}{$1.0 \mathrm{~K} / \mathrm{s}$} \\
\hline Cells & $\begin{array}{l}\text { Thermo- } \\
\text { Couples }\end{array}$ & $\begin{array}{l}\text { Start Time } \\
\text { (s) }\end{array}$ & $\begin{array}{l}\text { Duration } \\
\text { (s) }\end{array}$ & $\begin{array}{c}\text { Temperature } \\
\text { Rate (K/s) }\end{array}$ & $\begin{array}{l}\text { Start Time } \\
\text { (s) }\end{array}$ & $\begin{array}{l}\text { Duration } \\
\text { (s) }\end{array}$ & $\begin{array}{c}\text { Temperature } \\
\text { Rate (K/s) }\end{array}$ \\
\hline $\mathrm{C} 2$ & $\mathrm{~T} 1$ & 2379 & 83 & 3.46 & 2389 & 71 & 3.94 \\
\hline $\mathrm{C} 3$ & $\mathrm{~T} 2$ & 2156 & 108 & 3.00 & 2157 & 90 & 3.45 \\
\hline $\mathrm{C} 4$ & T3 & 1755 & 224 & 1.27 & 1761 & 142 & 1.64 \\
\hline C5 & $\mathrm{T} 4$ & 1422 & 102 & 2.90 & 1422 & 90 & 3.22 \\
\hline C6 & T5 & 1101 & 58 & 5.54 & 1101 & 57 & 5.62 \\
\hline \multirow{2}{*}{$\mathrm{C} 7$} & T6 & 749 & 120 & 2.75 & 749 & 103 & 3.07 \\
\hline & $\mathrm{T} 7$ & 748 & 145 & 1.64 & 749 & 130 & 1.77 \\
\hline $\mathrm{C} 8$ & $\mathrm{~T} 8$ & 1174 & 106 & 1.84 & 1181 & 99 & 1.92 \\
\hline C9 & T9 & 1325 & 113 & 2.67 & 1329 & 103 & 2.86 \\
\hline $\mathrm{C} 10$ & $\mathrm{~T} 10$ & 1645 & 143 & 1.29 & 1657 & 103 & 1.49 \\
\hline $\mathrm{C} 11$ & $\mathrm{~T} 11$ & 2095 & 153 & 1.84 & 2096 & 150 & 1.86 \\
\hline
\end{tabular}

In the runaway process of a module, the high TRIs of one cell could result from not only itself ISC, but the flames of adjacent cells. Table 5 lists the TRIs of $0.5 \mathrm{~K} / \mathrm{s}$ caused by the thermal propagation of the flames of adjacent cells. The onset temperature on average is about $74{ }^{\circ} \mathrm{C}$. Between 748 and $878 \mathrm{~s}$, C7 burned intensely, ignited the wire harness above the module, and released extra heat to elevate the pole temperatures of $\mathrm{C} 6$ and C8 rapidly. From $783 \mathrm{~s}$, both T5 and T8 had the TRIs of $0.5 \mathrm{~K} / \mathrm{s}$ with respective durations of 66 and $50 \mathrm{~s}$. Nevertheless, T5 also had the TRI of $1.0 \mathrm{~K} / \mathrm{s}$ between 831 and $848 \mathrm{~s}$ with $5.7 \mathrm{~K} / \mathrm{s}$ in average. It was probable for the wire harness to be ignited by the jet flames of farther cells. The venting flames of $\mathrm{C} 9$ extended with wind and ignited the wire harness above $\mathrm{C} 4$, which caused T3 for a 20-s TRI of $0.5 \mathrm{~K} / \mathrm{s}$. Furthermore, the big fire of C9 heated T10 to cause a 22-s TRI. In addition, one battery pole could produce a high TRI by its own flames before ISC. T11 had a $10 \mathrm{~s}$ TRI of $1.0 \mathrm{~K} / \mathrm{s}$ from $1849 \mathrm{~s}$, which is $241 \mathrm{~s}$ earlier than the onset time of itself ISC. It was found that the durations of the TRIs of $1.0 \mathrm{~K} / \mathrm{s}$ greater than $50 \mathrm{~s}$ was caused only by ISC, over three times of that by thermal propagation. However, the duration of the TRIs of $0.5 \mathrm{~K} / \mathrm{s}$ greater than $50 \mathrm{~s}$ could be provoked by both ISC and thermal propagation.

Table 5 . High temperature rate intervals of $0.5 \mathrm{~K} / \mathrm{s}$ by thermal runaway propagation.

\begin{tabular}{ccccccc}
\hline Cells & $\begin{array}{c}\text { Thermo- } \\
\text { Couples }\end{array}$ & $\begin{array}{c}\text { Start Time } \\
\text { (s) }\end{array}$ & $\begin{array}{c}\text { Temperature } \\
\left({ }^{\circ} \mathbf{C}\right)\end{array}$ & $\begin{array}{c}\text { Duration } \\
\mathbf{( s )}\end{array}$ & $\begin{array}{c}\text { Average } \\
\text { Rate (K/s) }\end{array}$ & Causes \\
\hline C4 & T3 & 1293 & 47.4 & 20 & 0.62 & $\begin{array}{c}\text { The flame of C9 ignited the wire } \\
\text { harness above C4. }\end{array}$ \\
\hline C6 & T5 & 783 & 70.35 & 66 & 2.05 & $\begin{array}{c}\text { The ISC flame of C7 ignited the } \\
\text { wire harness above C6. }\end{array}$ \\
\hline C8 & T8 & 783 & 62.1 & 50 & 0.7 & $\begin{array}{c}\text { The ISC flame of C7 ignited the } \\
\text { wire harness above C8. }\end{array}$ \\
\hline C9 & T9 & 1204 & 73.65 & 23 & 0.78 & $\begin{array}{c}\text { The ISC flame of C8 ignited the } \\
\text { wire harness above C9. }\end{array}$ \\
\hline C10 & T10 & 1328 & 63.35 & 22 & 0.83 & $\begin{array}{c}\text { The ISC flame of C9 took effects } \\
\text { on C10. }\end{array}$ \\
\hline
\end{tabular}

Researchers have validated that the SEI decomposition inside LIBs generates gases and exothermic spikes [21,23]. In the case of a prismatic cell, the gas production can increase the internal pressure for the safety valve rupture. At the same time, the exothermic spikes can elevate battery temperatures transiently. Therefore, when one cell is in thermal abuse, there seems to be a certain relationship 
between the time of the first gas eruption and the sudden change of the pole temperature rate. In Figure 9a-c, T6, T5, and T8 have temperature rate spikes more than $1.8 \mathrm{~K} / \mathrm{s}$ at time 542, 904, and 948 $\mathrm{s}$, respectively, for at least 10 times of $\mathrm{pT}_{\mathrm{AB}}$ in Figure 8. Additionally, the temperature rate spikes of $\mathrm{T} 5$ and $\mathrm{T} 6$ are beyond 3.8 and $10.5 \mathrm{~K} / \mathrm{s}$, respectively. Their temperatures are greater than $90{ }^{\circ} \mathrm{C}$. Table 6 shows that $\mathrm{C} 7, \mathrm{C} 6$, and $\mathrm{C} 8$ erupted gas about $10 \mathrm{~s}$ after their own pole temperature rate spikes of $\mathrm{T} 6$, $\mathrm{T} 5$, and $\mathrm{T} 8$, respectively.

Table 6. Pole temperature rate spikes and first gas eruption.

\begin{tabular}{|c|c|c|c|c|c|c|c|}
\hline \multirow[b]{2}{*}{ Cells } & \multirow{2}{*}{$\begin{array}{l}\text { Thermo- } \\
\text { Couples }\end{array}$} & \multicolumn{3}{|c|}{ Temperature Rate Spike } & \multicolumn{3}{|c|}{ First Gas Eruption } \\
\hline & & $\begin{array}{c}\text { Values } \\
\text { (K/s) }\end{array}$ & $\begin{array}{c}\text { Temperatures } \\
\left({ }^{\circ} \mathrm{C}\right)\end{array}$ & Time (s) & $\begin{array}{c}\text { Values } \\
(\mathrm{K} / \mathrm{s})\end{array}$ & $\begin{array}{c}\text { Temperatures } \\
\left({ }^{\circ} \mathrm{C}\right)\end{array}$ & $\begin{array}{c}\text { Time } \\
\text { (s) }\end{array}$ \\
\hline \multirow{2}{*}{ C6 } & $\mathrm{T} 5$ & 3.8 & 162 & \multirow{2}{*}{904} & -0.55 & 162 & \multirow{2}{*}{914} \\
\hline & T6 & 10.5 & 484 & & -0.25 & 491 & \\
\hline \multirow{2}{*}{$\mathrm{C} 7$} & T6 & 1.8 & 93 & \multirow{2}{*}{542} & 0.3 & 95 & \multirow{2}{*}{552} \\
\hline & $\mathrm{T} 7$ & 0.25 & 93 & & 0.25 & 95 & \\
\hline $\mathrm{C} 8$ & $\mathrm{~T} 7$ & 0.1 & 359 & 948 & -0.85 & 355 & 957 \\
\hline
\end{tabular}

In summaries, the pole temperatures and their rates can be applied to predict what time some behaviors of the abused battery happen, including the initial gas eruption and ISC. That the duration of the TRI of $1.0 \mathrm{~K} / \mathrm{s}$ is greater than $20 \mathrm{~s}$ can be used to indicate the ISC generation in the module. It is also probable to be in the risk of gas venting when a pole temperature rate spike exceeds $1.8 \mathrm{~K} / \mathrm{s}$, which is over 10 times of its forgoing average value, and its temperatures sustain above $90^{\circ} \mathrm{C}$ for more than $10 \mathrm{~s}$.

\subsection{Thermal Runaway Propagation Time}

When one cell thermally runs away in a battery pack, the heat of its exothermic reaction can be transferred to adjacent cells. It is probable that this thermal propagation makes normal cells abused thermally into runaway. The thermal propagation time is defined to indicate the triggering progress of runaway cells in a battery pack [18].

$$
\Delta t_{k}=t_{k+1}-t_{k}
$$

where $\Delta t_{k}$ denotes the thermal propagation time, $\mathrm{s}, t_{k}$ denotes the onset time of one runaway cell, $\mathrm{s}$, and $k$ denotes the number of the triggering sequence of runaway cells in a battery pack, $k=1,2, \ldots, 10$.

When one cell thermally runs away in the LIB pack, the heat of its exothermic reaction is transferred to adjacent cells. This thermal propagation likely makes the normal cells abused thermally into runaway. According to the observed phenomena of smoke and fire, the runaway sequence of 12 cells in the battery module was $\mathrm{C} 7 \rightarrow \mathrm{C} 6 \rightarrow \mathrm{C} 8 \rightarrow \mathrm{C} 9 \rightarrow \mathrm{C} 5 \rightarrow \mathrm{C} 10 \rightarrow \mathrm{C} 4 \rightarrow \mathrm{C} 11 \rightarrow \mathrm{C} 3 \rightarrow \mathrm{C} 12 \rightarrow \mathrm{C} 2 \rightarrow \mathrm{C} 1$. On both sides of $\mathrm{C} 7$, the cells triggered thermal runaway one by one from the inside to the outside. Table 7 lists the thermal runaway propagation time (TRPT) between both cells in the module.

Table 7. Thermal runaway propagation time.

\begin{tabular}{ccccccccccccc}
\hline Cells & C7 & C6 & C8 & C9 & C5 & C10 & C4 & C11 & C3 & C12 & C2 & C1 \\
\hline$k$ & 1 & 2 & 3 & 4 & 5 & 6 & 7 & 8 & 9 & 10 & 11 & 12 \\
\hline$\Delta t_{k}(\mathrm{~s})$ & 0 & 362 & 43 & 331 & 132 & 121 & 155 & 152 & 125 & 273 & 87 & 264 \\
\hline
\end{tabular}

Overall, the maximum, average, and minimum of the TRPT are $362 \mathrm{~s}, 186 \mathrm{~s}$, and $43 \mathrm{~s}$, respectively. Due to different thermal environments, internal energy changes, and exothermic reaction time length, thermal runaway propagates unevenly and the TRPT varies, which is also validated in other 
studies $[18,19]$. The heat insulation layers, abuse types, and energy levels can change the TRPT. The average TRPT is around $183 \mathrm{~s}$ by using the thermal resistant layers of asbestos and puncture [18]. Compared to the $100 \%$ SOC, the average TRPT increases by $70 \%$ at around $306 \mathrm{~s}$ for the $50 \%$ SOC even if the cells directly contact through their metal shells [19]. The average value of thermal runaway duration of each battery cell is $382 \mathrm{~s}$, which is at least two times of the average value of the TRPT of each battery cell. This indicates the thermal runaway processes of battery cells overlapped during the thermal runaway propagation in the module. Although the TRPT on both sides of C7 calculated from Table 7 is different and varies between 253 and $506 \mathrm{~s}$, it is surprising that its average value on each side almost equals about $340 \mathrm{~s}$.

\subsection{Thermal Runaway Propagation Capability}

A large amount of heat is released when one cell occurred with an ISC in the battery module. The thermal impacts on its adjacent cells can be expressed by using enthalpy. On one hand, the module is a thermodynamic system, and the thermal energy change can be characterized by its enthalpy change. On the other hand, the enthalpy changes between adjacent cells are interrelated. Their relationship can be figured out by using a correlation coefficient.

$$
\gamma\left(C_{T R}, C_{u T R}\right)=\frac{\Delta H_{u T R}}{\Delta H_{T R}} \rho_{H}\left(C_{T R}, C_{u T R}\right) \times 100 \%
$$

where $\gamma\left(C_{T R}, C_{u T R}\right)$ denotes the thermal runaway propagation coefficient, $C_{T R}$ and $\Delta H_{T R}$ denote the thermal runaway cell and its enthalpy change, $C_{u T R}$ and $\Delta H_{u T R}$ denote the adjacent cell and its enthalpy change, and $\rho_{H}\left(C_{T R}, C_{u T R}\right)$ denotes the correlation coefficient of the enthalpy changes.

During the thermal runaway, the internal temperature, pressure, and volume can be variable inside one cell, which are high cost to be measured on board. Because of no real-time data available in literature and only being dependent on the thermocouples, the change of its pressure and volume is ignored for simplicity. Its enthalpy change can be expressed as shown below.

$$
\begin{gathered}
\Delta H_{u T R}=C_{s, u T R} m_{u T R} \Delta T_{u T R} \\
\Delta H_{T R}=C_{s, T R} m_{T R} \Delta T_{T R}
\end{gathered}
$$

where $C_{s, T R}, m_{T R}$, and $\Delta T_{T R}$ denote the heat specific capacity, mass, and temperature rise of the cell $C_{T R}$, respectively. $C_{s, u T R}, m_{u T R}$, and $\Delta T_{u T R}$ denote the heat specific capacity, mass, and temperature rise of the cell $C_{u T R}$.

By substituting Equations (3) and (4) into Equation (2), we obtain the following.

$$
\gamma\left(C_{T R}, C_{u T R}\right)=\frac{C_{u T R} m_{u T R} \Delta T_{u T R}}{C_{T R} m_{T R} \Delta T_{T R}} \rho_{\mathrm{H}}\left(C_{T R}, C_{u T R}\right) \times 100 \%
$$

Due to the gas eruption and burning of the thermal runaway cell, its mass decreases and the heat specific capacity can be variable, which is both high cost and difficult to measure in real time. For simplicity, it is assumed that the heat specific capacity and mass of Equation (5) can be kept constant, so Equation (5) can be predigested as follows.

$$
\gamma\left(C_{T R}, C_{u T R}\right)=\frac{\Delta T_{u T R}}{\Delta T_{T R}} \rho_{T}\left(C_{T R}, C_{u T R}\right) \times 100 \%
$$

where, $\rho_{T}\left(C_{T R}, C_{u T R}\right)$ denotes the correlation coefficient of the temperature changes.

Equation (6) shows that $\gamma\left(C_{T R}, C_{u T R}\right)$ becomes a function of the temperature time sequences of adjacent cells. Table 8 lists $C_{T R}, C_{u T R}, \Delta T_{T R}, \Delta T_{u T R}, \rho_{T}$, and $\gamma$ by using the ISC data of the TRI of $0 \mathrm{~K} / \mathrm{s}$ in Table 3 . There are eight positive correlation coefficients of $\rho_{T}$ with the maximum, average, and minimum values of $0.99,0.86$, and 0.95 , respectively. Although there is one negative correlation coefficient, all 
thermal propagation coefficients of $\gamma$ are positive, and the maximum, average, and minimum values are $31 \%, 18.93 \%$, and $1.3 \%$, respectively. The average value of $\gamma$ is $24 \%$ in the right cells of C7 is about 1.8 times that of its left cells. This may be used to explain that the right cells underwent thermal runaway earlier than the left in the test. After the thermal runaway of C7, C6, and C8 occurred, the cells on the right side of $\mathrm{C} 8$ and left side of $\mathrm{C} 6$ initiated thermal runaway in turn, and the right cell $\mathrm{C} 9$ was the first.

Table 8. Parameters of thermal runaway propagation.

\begin{tabular}{cccccc}
\hline$C_{T R}$ & $C_{u T R}$ & $\rho$ & $\Delta T_{T R}\left({ }^{\circ} \mathrm{C}\right)$ & $\Delta T_{u T R}\left({ }^{\circ} \mathrm{C}\right)$ & $\gamma$ \\
\hline C3 & C2 & 0.95 & 330.1 & 29.4 & $8.5 \%$ \\
\hline C4 & C3 & 0.97 & 289.2 & 63.2 & $21 \%$ \\
\hline C5 & C4 & -0.70 & 299.5 & -5.4 & $1.3 \%$ \\
\hline C6 & C5 & 0.86 & 327.0 & 13.7 & $3.6 \%$ \\
\hline \multirow{2}{*}{ C7 } & C6 & 0.88 & 334.9 & 116.9 & $31 \%$ \\
\cline { 2 - 6 } & C8 & 0.98 & 230.7 & 56.7 & $24 \%$ \\
\hline C8 & C9 & 0.99 & 197.5 & 60.5 & $30 \%$ \\
\hline C9 & C10 & 0.90 & 306.4 & 39.4 & $12 \%$ \\
\hline C10 & C11 & 0.99 & 195.1 & 59.3 & $30 \%$ \\
\hline
\end{tabular}

The greater $\gamma$ is, the earlier thermal runaway of the adjacent cells should occur. Except the leftmost and rightmost cells, one cell has two adjacent cells in the module. C7 first triggered thermal runaway, the heat of which could be transferred to $\mathrm{C} 6$ and $C 8$. The temperature rise of $\mathrm{C} 6$ is more than two times that of $\mathrm{C} 8$ even though $\rho_{T}$ between $\mathrm{C} 6$ and $\mathrm{C} 7$ is 0.1 smaller than that between $\mathrm{C} 8$ and $\mathrm{C} 7$. Therefore, $\gamma$ between $\mathrm{C} 6$ and $\mathrm{C} 7$ is $7 \%$ greater than that between $\mathrm{C} 8$ and $\mathrm{C} 7$. This shows that $\mathrm{C} 6$ can absorb more heat from $\mathrm{C} 7$ and initiate earlier runaway than $\mathrm{C} 8$. In practice, $\mathrm{C} 6$ entered thermal runaway 43 s earlier than $\mathrm{C} 8$. Following the thermal runaway of $\mathrm{C} 6, \mathrm{C} 8$ started its runaway process. Because $\gamma$ between $\mathrm{C} 6$ and $\mathrm{C} 5$ is $3.6 \%$ less than one eighth of that between C8 and C9 in Table 8, C5 should be thermal runaway later than $\mathrm{C} 9$, which agrees with the experiment results.

Between $1420 \mathrm{~s}$ and $1527 \mathrm{~s}$, C5 underwent ISC to make T4 a high temperature rate of $3.2 \mathrm{~K} / \mathrm{s}$. However, $\mathrm{C} 4$ absorbed heat to degrade $\mathrm{T} 3$ from $105.6{ }^{\circ} \mathrm{C}$ to $100.2{ }^{\circ} \mathrm{C}$ in the interval. Therefore, $\rho_{T}$ between $C 5$ and $C 4$ is negative, and yet $\gamma$ is a small positive number of $1.3 \%$. In Table $8, \Delta T_{T R}$ is greater than $0 . \gamma$ is always positive because $\Delta T_{u T R}$ and $\rho$ are simultaneously positive or negative.

Through the above examples, the proposed thermal runaway propagation coefficient can characterize the capability of heat transfer between the runaway cell and adjacent cell. The greater the thermal runaway propagation coefficient, the more the heat transfer is, and vice versa. It can also can be applied for indexing heat insulation between cells in a battery pack.

\subsection{Audio Characteristics of Gas Venting}

In the process of thermal abuse, the cell could emit the sound of gas eruption. For instance, C7, C6, and C8 made sounds at their first gas eruption, which occurred, respectively, at about 200, 218, and $216 \mathrm{~s}$ earlier than that of ignition.

Audio signal can be quasi-steady-state and time-varying. The short-time analysis (STE) technology is often applied to figure out the feature parameters of each frame of sound data including amplitude, frequency, and energy [34]. An audio data can be expressed as follows.

$$
x_{k}(n)=x[[k-1] * d+n] * w(n)
$$

where $n$ and $L$, respectively, denote the position and length of audio data frame, $1 \leq n \leq L . x(n)$ is the digital audio data. $k, M$, and $d$, respectively, denote the frame number, the sub-frame number, and 
the frame offset of $x(n) .1 \leq k \leq M . x k(n)$ denotes the $k$ th audio signal. Additionally, $w(n)$ denotes the window signal.

The short time energy (STE) of each frame audio data can be written as below.

$$
\begin{gathered}
E_{k}=\sum_{n=1}^{L} x_{k}^{2}(n) \\
E_{k \%}=E_{k} / \max _{k=1}^{M}\left(E_{k}\right)
\end{gathered}
$$

where $E_{k}$ denotes the STE of the $k$ th audio data frame. $E_{k} \%$ denotes the normalization of $E_{k}$.

Base frequency is the vibration frequency of vocal cords. It is one of the most important parameters of speech signals. Similarly, the excitation source frequency of the gas eruption sound of a battery cell can be extracted by using the Fourier transform and the inverse Fourier transform.

$$
\begin{gathered}
X_{k}(\omega)=\sum_{m=1}^{L}\left[x_{k}[m] e^{-j \omega m}\right] \\
X_{\mathrm{I} k}(\omega)=\frac{1}{L} \sum_{m=1}^{L}\left\{\left[\ln \left|X_{k}\right| \omega \|\right] e^{j \omega m}\right\} \\
f_{b}=f_{s} / \max \left(X_{I k}\right)
\end{gathered}
$$

where $X_{k}(\omega)$ denotes the frequency spectrum of $x_{k}(n) . X_{I k}(\omega)$ denotes the inverse spectrum of $x_{k}(n)$. $f_{s}$ denotes the sample frequency. In addition, $f_{b}$ denotes the base frequency.

By using Equations (7)-(12), Figure 10 shows that the characteristics of the short gas eruption sound of C7, C6, and C8. Although the venting sounds of these three cells occurred at different time periods and temperatures, their signals tended to be similar. In Figure 10a, the shapes of three audio digital signals are indistinguishable. C7 has the most audio peak value of 0.915 , where both $\mathrm{C} 6$ and C8 exceed the $90 \%$ value. In Figure 10b, the three base frequencies of C7, C6, and C8 are $494 \mathrm{~Hz}$, $500 \mathrm{~Hz}$, and $510 \mathrm{~Hz}$, respectively. They behave similarly. In Figure 10c, the three STE shapes of C7, C6, and C8 tend almost identically. It is solely that they differ in magnitude. Additionally, the STE amplitudes of both $\mathrm{C} 6$ and $\mathrm{C} 8$ are, respectively, $80 \%$ and $85 \%$ of that of $\mathrm{C} 7$. Additionally, the audio signal of C8 is mixed with a little noise. Its normalized STE value of the noise is less than 0.25 . It is helpful for us to identify whether the jet gas occurs for a prismatic cell in thermal abuse through the audio characteristic data. 


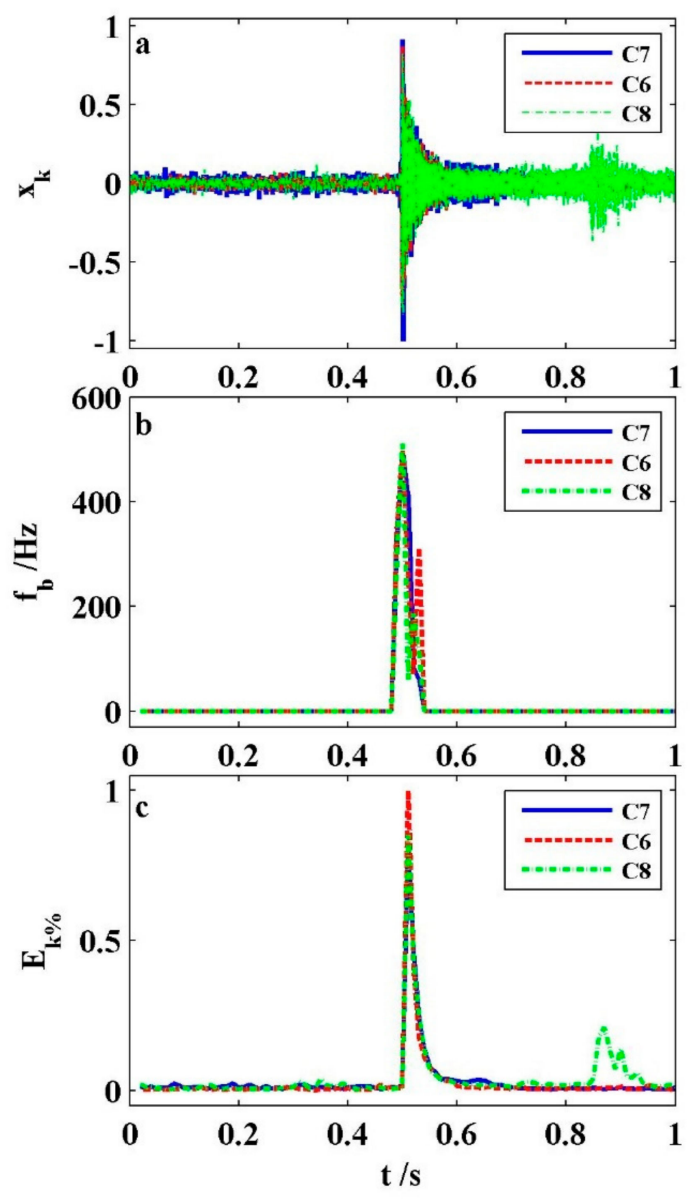

Figure 10. Sound characteristics of gas eruption at first: (a) digital audio, (b) base frequencies, and (c) short-time energies.

\section{Conclusions}

Thermal abuse behaviors were profiled and characterized for a central overheat-induced thermal runaway propagation inside a large prismatic lithium-ion battery module based on the experimental audio-video records and pole temperature data. From the centrality to both sides, all 12 cells underwent thermal runaway. The main outputs of this work are summarized as follows.

The thermal abuse process of the battery module can be divided into several stages, mainly including the germination, propagation, and termination of thermal runaway. Meanwhile, the gas eruption, the fire ejection, and the flame combustion are typical phenomena. The gas eruption is the first phenomenon for about $200 \mathrm{~s}$ before fire. The color of jet gas can change during venting of either one cell or different cells. Additionally, the flames burn around 100 to $500 \mathrm{~s}$. Furthermore, the gas and fire can alternately erupt and sustain beyond $10 \mathrm{~s}$.

The first three thermal runaway cells erupt gas first and not less than $200 \mathrm{~s}$ earlier than ignite. The jet gas sounds less than $1 \mathrm{~s}$ and tends to be similar in the midst of close amplitudes, frequencies, and energies by using the short-time analysis technology. Moreover, each pole temperature rate behaves greater than $1.8 \mathrm{~K} / \mathrm{s}$ spike about $10 \mathrm{~s}$ before the short gas eruption.

Both the internal short circuit and thermal runaway propagation can cause high pole temperature rates. However, the duration of the temperature rate interval of $1.0 \mathrm{~K} / \mathrm{s}$ by the internal short circuit is more than three times of that by the thermal runaway propagation. The internal short circuit of each cell in thermal runaway can be characterized by using the temperature rate interval of $1.0 \mathrm{~K} / \mathrm{s}$ with the duration greater than $20 \mathrm{~s}$. The corresponding pole temperatures exceed $120^{\circ} \mathrm{C}$. 
The thermal runaway propagates from the central to both sides. The average time of thermal runaway propagation is about $186 \mathrm{~s}$ for all, and $340 \mathrm{~s}$ per side. However, the cells on both sides do not completely alternate to trigger thermal runaway, which can be elucidated by the proposed thermal runaway propagation coefficient. The greater this coefficient is, the more easily it activates the cell's thermal runaway adjacent to the ISC venting cell.

This work has focused on the relationships between cell behaviors and physical quantities during the thermal abuse process in a large prismatic 12S1P battery module. This investigation exemplifies that we can have adequate time to warn the occurrence of severe thermal runaway of onboard battery packs with the early characteristics. It is regrettable that the battery terminal voltage is not detected. If it is sensed in the test, the internal circuit short initiation can be more clearly confirmed at least. Additionally, some phenomena cause variable colors of the venting gas. Alternate ejection of flame and gas need to be explained by many more tests. In the future, we will continue to study the mechanical abuse behaviors and explore the fault diagnosis methods of thermal runaway propagation of lithium-ion batteries for electric vehicle applications.

Author Contributions: Conceptualization and measurements, X.R. Formal analysis, X.C. Writing, X.C. and T.L. Project administration, X.R. and Z.W. All authors have approved the manuscript.

Funding: The BNET Blueway New Energy Technology Co. Ltd., the National Nature Science Foundation of China (No. 51677006), and MOST (Ministry of Science and Technology) of China under the contract (No. 2018YFB0106) funded this research.

Acknowledgments: The authors appreciate the BNET Blueway New Energy Technology Co. Ltd. and her workers for the experimental support.

Conflicts of Interest: The authors declare no conflict of interest.

\section{References}

1. Tobishima, S.I.; Yamaki, J.I. A consideration of lithium cell safety. J. Power Sources 1999, 81, 882-886. [CrossRef]

2. Wen, J.; Yu, Y.; Chen, C. A Review on Lithium-Ion Batteries Safety Issues: Existing Problems and Possible Solutions. Mater. Express 2012, 2, 197-212. [CrossRef]

3. Balakrishnan, P.G.; Ramesh, R.; Kumar, T.P. Safety mechanisms in lithium-ion batteries. J. Power Sources 2006, 155, 401-404. [CrossRef]

4. Bandhauer, T.M.; Garimella, S.; Fuller, T.F. A Critical Review of Thermal Issues in Lithium-Ion Batteries. J. Electrochem. Soc. 2011, 158, R1-R25. [CrossRef]

5. Lisbona, D.; Snee, T. A review of hazards associated with primary lithium and lithium-ion batteries. Process Saf. Environ. Prot. 2011, 89, 434-442. [CrossRef]

6. Wang, Q.; Ping, P.; Zhao, X.; Chu, G.; Sun, J.; Chen, C. Thermal runaway caused fire and explosion of lithium ion battery. J. Power Sources 2012, 208, 210-224. [CrossRef]

7. Ruiz, V.; Pfrang, A.; Kriston, A.; Omar, N.; Van den Bossche, P.; Boon-Brett, L. A review of international abuse testing standards and regulations for lithium ion batteries in electric and hybrid electric vehicles. Renew. Sustain. Energy Rev. 2018, 81, 1427-1452. [CrossRef]

8. Feng, X.; Ouyang, M.; Liu, X.; Lu, L.; Xia, Y.; He, X. Thermal runaway mechanism of lithium ion battery for electric vehicles: A review. Energy Storage Mater. 2018, 10, 246-267. [CrossRef]

9. Lamb, J.; Orendorff, C.J.; Steele, L.A.; Spangler, S.W. Failure propagation in multi-cell lithium ion batteries. J. Power Sources 2015, 283, 517-523. [CrossRef]

10. Lopez, C.F.; Jeevarajan, J.A.; Mukherjee, P.P. Experimental Analysis of Thermal Runaway and Propagation in Lithium-Ion Battery Modules. J. Electrochem. Soc. 2015, 162, A1905-A1915. [CrossRef]

11. Jeevarajan, J.A. Hazards Associated with High Voltage High Capacity Lithium-ion Batteries. ECST 2011, 33 , $1-6$.

12. Ouyang, D.; Liu, J.; Chen, M.; Weng, J.; Wang, J. An Experimental Study on the Thermal Failure Propagation in Lithium-Ion Battery Pack. J. Electrochem. Soc. 2018, 165, A2184-A2193. [CrossRef]

13. Zhong, G.; Li, H.; Wang, C.; Xu, K.; Wang, Q. Experimental Analysis of Thermal Runaway Propagation Risk within 18650 Lithium-Ion Battery Modules. J. Electrochem. Soc. 2018, 165, A1925-A1934. [CrossRef] 
14. Spotnitz, R.M.; Weaver, J.; Yeduvaka, G.; Doughty, D.H.; Roth, E.P. Simulation of abuse tolerance of lithium-ion battery packs. J. Power Sources 2007, 163, 1080-1086. [CrossRef]

15. Coman, P.T.; Darcy, E.C.; Veje, C.T.; White, R.E. Numerical analysis of heat propagation in a battery pack using a novel technology for triggering thermal runaway. Appl. Energy 2017, 203, 189-200. [CrossRef]

16. Xu, J.; Lan, C.; Qiao, Y.; Ma, Y. Prevent thermal runaway of lithium-ion batteries with minichannel cooling. Appl. Therm. Eng. 2017, 110, 883-890. [CrossRef]

17. Wilke, S.; Schweitzer, B.; Khateeb, S.; Al-Hallaj, S. Preventing thermal runaway propagation in lithium ion battery packs using a phase change composite material: An experimental study. J. Power Sources 2017, 340, 51-59. [CrossRef]

18. Feng, X.; Sun, J.; Ouyang, M.; Wang, F.; He, X.; Lu, L.; Peng, H. Characterization of penetration induced thermal runaway propagation process within a large format lithium ion battery module. J. Power Sources 2015, 275, 261-273. [CrossRef]

19. Li, H.; Duan, Q.; Zhao, C.; Huang, Z.; Wang, Q. Experimental investigation on the thermal runaway and its propagation in the large format battery module with $\mathrm{Li}(\mathrm{Ni1} / 3 \mathrm{Co} 1 / 3 \mathrm{Mn} 1 / 3) \mathrm{O} 2$ as cathode. J. Hazard. 2019, in press. [CrossRef]

20. Krause, L.J.; Lamanna, W.; Summerfield, J.; Engle, M.; Korba, G.; Loch, R.; Atanasoski, R. Corrosion of aluminum at high voltages in non-aqueous electrolytes containing perfluoroalkylsulfonyl imides; new lithium salts for lithium-ion cells. J. Power Sources 1997, 68, 320-325. [CrossRef]

21. Roth, E.P.; Orendorff, C.J. How Electrolytes Influence Battery Safety. Electrochem. Soc. Interface 2012, 21, 45-49. [CrossRef]

22. Richard, M.N.; Dahn, J.R. Accelerating rate calorimetry study on the thermal stability of lithium intercalated graphite in electrolyte. I. Experimental. J. Electrochem. Soc. 1999, 146, 2068-2077. [CrossRef]

23. Spotnitz, R.; Franklin, J. Abuse behavior of high-power lithium-ion cells. J. Power Sources 2003, 113, 81-100. [CrossRef]

24. Wang, Q.; Sun, J.; Yao, X.; Chen, C. Thermal stability of LiPF6/EC + DEC electrolyte with charged electrodes for lithium ion batteries. Thermochim. Acta 2005, 437, 12-16. [CrossRef]

25. Haik, O.; Ganin, S.; Gershinsky, G. On the Thermal Behavior of Lithium Intercalated Graphites. J. Electrochem. Soc. 2011, 158, A913-A923. [CrossRef]

26. Roder, P.; Baba, N.; Wiemhofer, H.D. A detailed thermal study of a Li[Ni0.33Co0.33Mn0.33] $\mathrm{O}_{2} / \mathrm{LiMn}_{2} \mathrm{O}_{4}$-based lithium ion cell by accelerating rate and differential scanning calorimetry. J. Power Sources 2014, 248, 978-987. [CrossRef]

27. Koch, S.; Fill, A.; Birke, K.P. Comprehensive gas analysis on large scale automotive lithium-ion cells in thermal runaway. J. Power Sources 2018, 398, 106-112. [CrossRef]

28. Larsson, F.; Andersson, P.; Blomqvist, P.; Mellander, B.E. Toxic fluoride gas emissions from lithium-ion battery fires. Sci. Rep. 2017, 7, 10018. [CrossRef]

29. Finegan, D.P.; Darcy, E.; Keyser, M.; Tjaden, B.; Heenan, T.M.; Jervis, R.; Bailey, J.J.; Malik, R.; Vo, N.T.; Magdysyuk, O.V.; et al. Characterising thermal runaway within lithium-ion cells by inducing and monitoring internal short circuits. Energy Environ. Sci. 2017, 10, 1377-1388. [CrossRef]

30. Harris, S.J.; Timmons, A.; Pitz, W.J. A combustion chemistry analysis of carbonate solvents used in Li-ion batteries. J. Power Sources 2009, 193, 855-858. [CrossRef]

31. Venugopal, G.; Moore, J.; Howard, J.; Pendalwar, S. Characterization of microporous separators for lithium-ion batteries. J. Power Sources 1999, 77, 34-41. [CrossRef]

32. Yan, S.; Deng, J.; Bae, C.; Xiao, X. Thermal expansion/shrinkage measurement of battery separators using a dynamic mechanical analyzer. Polym. Test. 2018, 71, 65-71. [CrossRef]

33. Coman, P.T.; Darcy, E.C.; Veje, C.T.; White, R.E. Modelling Li-Ion Cell Thermal Runaway Triggered by an Internal Short Circuit Device Using an Efficiency Factor and Arrhenius Formulations. J. Electrochem. Soc. 2017, 164, A587-A593. [CrossRef]

34. Song, Z. Analysis and Synthesis of Speech Signals Using Matlab; Beihang University Press: Beijing, China, 2018.

(C) 2019 by the authors. Licensee MDPI, Basel, Switzerland. This article is an open access article distributed under the terms and conditions of the Creative Commons Attribution (CC BY) license (http://creativecommons.org/licenses/by/4.0/). 